\title{
Konferencia az európai információ- és kommunikáció-menedzsmentről
}

$\mathbf{M}$

Á

D

Így hivatkozzon erre a cikkre:

Kun László. „ Konferencia az európai információ- és kommunikáció-menedzsmentről”. Információs Társadalom VII, 1. szám (2007): 102-108.

= https://dx.doi.org/10.22503/inftars.VII.2007.1.9 

A folyóiratban közölt müvek a Creative Commons Nevezd meg! - Ne add el! - Így add tovább! 4.0 Nemzetközi Licenc feltételeinek megfelelően használhatók. 
Kun László

\section{Konferencia az európai információ- és kommunikációmenedzsmentrôl}

A European Institute of Public Administration 2006. november 30. és december 1. között rendezte meg Maastrichtban a European Information and Communication Management - Conference: Keep Ahead with European Information in the Enlarged Europe: Information and Communication Strategies elnevezésú konferenciáját, amelynek fóbb megállapításait mutatjuk be az alábbiakban.

Az Európai Unió - hasonlóan bármely más szervezethez - a megfeleló információáramlás bistosítása nélkül nyilvánvalóan múködésképtelen, vagyis lehetetlen egységként múködtetni, végrehajtatni a tervezett intézkedéseket, majd ellenórizni megtörténtüket. Az információáramlást egyrészt az Unió különféle szervezetein belül és azok között, másrészt az Unió szervezetei és polgárai között is biztosítani kell.

A konferencia fơ témáit az információáramlás alábbi eszközei és intézményei alkották:

- az uniós intézmények információszolgáltatása;

- az uniós stratégiák mind a kommunikáció, mind az információszolgáltatás terén;

- az elektronikus és a „hagyományos” adatbázisok és más információforrások (pl. EUR-

Lex, könyvek, folyóiratok kiadása);

- az elektronikus és a „hagyományos” kommunikációs csatornák.

A konferencia tehát nem a „klasszikus” információs társadalom és az e-kormányzás témaköreivel foglalkozott, azonban a fenti területek hosszú távon legalább olyan fontosak, mint az általában az információs társadalom fogalomköréhez sorolt témák. A kommunikációs és információszolgáltatási stratégiák meghatározó szerepet játszanak abban, hogy az információk elérése igénnyé, szükségletté váljon, a megfeleló információáramlás és információszolgáltatás pedig alapja és nélkülözhetetlen feltétele annak, hogy az információk igénybe vehetốk, felhasználhatók legyenek. Igények nélkül elképzelhetetlen az ún. információs társadalom kialakulása, és a nem megfelelô szolgáltatások visszavethetik ezt a folyamatot. A konferencia azt a - véleményem szerint helyes - szemléletet közvetítette, hogy jelentôs fejlôdés eléréséhez integrálni kell a különféle lépéseket, az információs társadalom témakörét nem lehet az egyéb társadalmi folyamatoktól elkülönítve vizsgálni.

Az Unió lépései - már csak méretüknél és hatásuknál fogva is - meghatározók, ezért mindenképpen követni kell ôket.

Az elmúlt néhány évnek az Európai Unió számára kedvezốtlen jelenségei (fóként az uniós alkotmány franciaországi és hollandiai leszavazása) rámutattak arra, hogy többek között a kommunikáció és az információszolgáltatás területén is stratégiaváltásra van szükség, továbbá kutatások, felmérések igazolták, hogy az Európai Unió polgárai nagyon keveset tudnak magáról az Unióról, annak múködéséról. 
Az EU döntéshozói ezért erósiteni kivánják a kommunikáció és az információáramlás szerepét, eszközeit, és jelentốs haladást kívánnak elérni az eddig igazán sikeresnek nem nevezhetố területeken.

Az elmúlt években több kezdeményezés indult abból a célból, hogy az eddigi kommunikációs és információs tevékenység módosításával, fejlesztésével az uniós intézmények és általában az egész Unió információszolgáltató tevékenysége javuljon, illetve a már meglévô adatbázisokat és egyéb információs bázisokat jot'oan ki tudják használni.

A konferencia a fentieknek megfelelően az alábbi négy témakörrel foglalkozott.

1. Az EU információs és kommunikációs stratégiái („Megismertetni Európát!”).

2. Az EU információs hálózatának szervezetei.

3. Nyitottság, átláthatóság és a releváns dokumentumokhoz való hozzáférés.

4. Az EU információs eszközei.

\section{Témakör: Az EU információs és kommunikációs stratégiái - "Megismertetni Európát!"}

Jelenleg az Uniónak nincs közös kommunikációs politikája, sem olyan egységes stratégiája, amely lehetôvé tenné a közös értékek és a közös célok megismertetését az Unió polgáraival. Felmérések során tíz emberból heten azt válaszolták, hogy csak kevéssé vagy egyáltalán nem ismerik az Uniót, és ha feltették a kérdést, hogy „Mi az Unió?”, akkor a legtöbb embernek sztereotip képek jutottak eszébe nagy irodaházakban székeló intézményekról és öltönyös fehér férfiakról zárt ajtók mögött (white men in suits behind closed doors): ez az a kép, ahogyan a többség az Uniót látja.

Uniós felmérés szerint az emberek 87 százaléka a televízióból nyeri az információkat, a lakosság kétharmad része mindennap néz híreket a televízióban, ám ennek ellenére a megkérdezettek egyharmada - saját bevallása szerint - nem kap elegendő tájékoztatást.

Az Unió feltett célja, hogy a már meglévő hagyományos lehetőségek mellett kihasználja az új kommunikációs eszközöket is (internet stb.).

Ezeknek az eszközöknek a felhasználása azonban nem egyszerú, ugyanis az európai média jelenleg nagyon szegmentált képet mutat: összesen 3660 tv-csatorna múködik, ebból 2330 regionális. 25 ezer újságíró foglalkozik uniós ügyekkel Európában, közülük 1175 Brüsszelben dolgozik.

Szükség van olyan lépésekre, amelyek lehetôvé teszik a helyzet megváltoztatását. Össze kell kötni az embereket egymással és az intézményekkel, és létre kell hozni az európai közösségi tereket, amelyek lehetnek

- valós, fizikai helyek;

- virtuális közösségi helyek (az interneten és egyéb hálózatokon); és

- az ezeket összekötő felhasználóbarát csatornák.

Komoly probléma az információs tuilterhelés (information overflow), ezért egyszerúbben használható, felhasználóbarátabb információs eszközöket kell építeni, beleértve az Unió portálját és a hozzá kapcsolódó honlapokat, adatbázisokat is. 
Az információáramlás és a kommunikáció szempontjából kiemelt szerepet játszanak a civil szervezetek. Jellemző, hogy ezek iránt általában jóval nagyobb bizalom nyilvánul meg, mint a politikusok iránt. A bizalomnak köszönhetôen a civil szervezetek összekötö kapcsot képezhetnek a politikusok és a ,nép” között, hídszerepet tudnak betölteni. Általában rugalmasabbak, kisebbek és gyorsabbak, mint a hagyományos politikai szereplók, ezért az egyes konkrét ügyek képviseletében és elóbbre vitelében jelentôs szerepet láthatnak el.

A konferencia egyik fontos elôadása az európai információáramlás és terjesztés fejlesztésére irányuló programokat mutatta be. Az előadás a következó négy területre koncentrált:

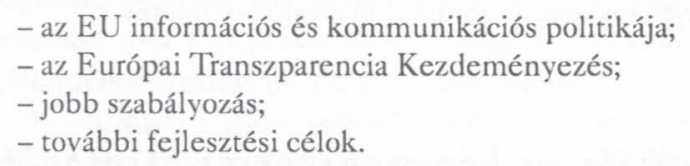

2006 februárjában jelent meg az európai kommunikációs politikáról szóló „Fehér Könyv" (White Paper), amelynek fö üzenete a következô: a kommunikáció terïletén közös fellépésre van sziikség, vagyis a polgárokat és a civil társadalmat be kell vonni a döntési folyamatokba. A Fehér Könyv meghatározta a média és az új technológiák szerepét, kiemelve az európai közvélemény megismerésének, a helyi szintek elérésének elvét (go local), valamint a nemzeti, helyi, illetve szektorális szereplók fontosságát.

Az Unió jelentôs fejlesztési programokat indított az adatbázisok és a publikációk területén is. Az EUR-Lex, az Unió joganyagát tartalmazó adatbázis, amelyben a jogi anyagok ingyenesen kereshetốk és letölthetốk, 2006-tól teljesen szabadon elérhetốvé vált. A közeljövóben elindítják az ún. N-Lex programot is, amely az uniós direktívák implementációjára vonatkozó nemzeti jogszabályokat fogja elérhetővé tenni az interneten keresztül.

\section{2. témakör: Az EU információs hálózata}

Az Unió információs hálózatát a konferencia két oldalról mutatta be, ezek közül az egyik az Unió különféle ügynökségeinek szerepe, a másik pedig egyes elektronikus eszközök használata volt.

Az Unió ügynökségei olyan szervezetek, amelyeket jogszabállyal hoznak létre valamilyen meghatározott cél érdekében. Jelenleg 35 uniós ügynökség múködik szerte Európában a legkülönbözóbb területeken, az élelmiszerbiztonságtól a környezetvédelmen és a drogmonitorozáson át a jogi együttmúködésig (az ügynökségek teljes listája megtalálható a http://europa.eu/agencies honlapon).

Az ügynökségek információs és kommunikációs tevékenysége az alábbi négy fố részból áll:

- kommunikációs stratégiák (sajtóközlemények, publikációk, internetes tartalmak, kiállítások és más rendezvények); 
- „veszélykommunikáció”, azaz a veszélyhelyzetekre való felkészülés és az erról szóló információk terjesztése;

- a közös uniós kommunikáció (közös publikációk, közös ügynökségi hálózati portál, hirdetések, magazinok megjelentetése);

- a különbözó szervezetek közötti kapcsolatépités.

Az Unió a „fizikai” hálózatokon kívül természetesen elektronikus hálózatokat is üzemeltet, amelyeknek a szerepe - hasonlóan a hagyományos információs rendszerekhez - az információk minél jobb és szélesebb terítése, továbbítása.

Minden ilyen hálózat közül ki kell emelni a Europe Direct hálózatot. A Europe Direct az Unió legjelentôsebb információszolgáltató hálózata, ami az egyszerú ügyfélszolgálati tevékenységtól indulva eljutott odáig, hogy több mint 400 szolgáltató ponton keresztül mưködô, integrált, teljes körû információszolgáltatóvá vált. Az első lépés egy brüsszeli call-center kialakítása volt, ahol a tagállamok lakói saját nyelvükön tehettek fel kérdéseket, illetve kaphattak rájuk választ. Emellett már korábban is léteztek az ún. Európai Dokumentációs Központok (European Documentation Centres, EDCs), amelyek közül a legrégibbek egyetemeken és hasonló létesítményekben épültek ki, alapvetôen kutatási céllal. A call-center és az EDC-hálózat viszonylag korlátozott lehetôségekkel bírt, ezért a korábbi központokat integrálják a Europe Direct hálózatba. Team Europe néven megalakítottak egy olyan, állandó szakértókból álló csoportot, amelynek tagjai a tagállamok állandó képviseletein keresztül érhetók el. A szakértóket előadások megtartására, tanfolyamok vezetésére és más hasonló feladatok ellátására lehet felkérni, így hasznosítva szaktudásukat.

A Europe Direct hálózat információs központjai (Europe Direct Information Centres) alábbi feladatai kritikus jelentőségúek az Unió szempontjából:

- az európai polgárok és döntéshozók segítése abban, hogy többet tudhassanak az Unióról és könnyebben elérhessék az uniós intézményeket;

- az Európáról folytatott diskurzus támogatása és erôsítése;

- lehetốség biztosítása a kérdésfeltevésre, a véleménynyilvánításra és a javaslattételre.

Az új Europe Direct hálózat kiépítése egy éve indult meg, szolgáltatásai ma mind a 25 tagállamban, több mint 400 ponton keresztül vehetók igénybe, ezenkívül új hálózati portál (http://ec.europa.eu/europedirect/index_hu.htm) is indult.

Az Európai Unió által fenntartott hálózatok mellett természetesen szükség van kiilsó hálózatokra és információforrásokra is. Az Unióról nem csak az Unió állít eló információs anyagokat, és az Unión belül szükség van más nézốpontokra is. Ebból a célból jött létre Nagy-Britanniában a European Sources Online elnevezésú szolgáltatás (http://www.europeansources.info/jsp/marketing/nonsub.jsp), melynek keretében közzéteszik az Unió hivatalos anyagait, de az adatbázis tartalmaz nem az Unió intézményei által kiadott, illetve nem az Unióban megjelent újságcikkeket és tanulmányokat is, folyamatos hírszolgáltatást nyújtva az Unió teljesítményének külsô megítéléséról. 


\section{3. témakör: Nyitottság, átláthatóság és a dokumentumokhoz való hozzáférés}

A témakör alapfelvetése, hogy a 2005. évi jelentés szerint az európai ombudsmanhoz benyújtott összes panasz 25 százaléka az átláthatóság hiányából fakad. Ennek feloldására a legjobb módszer $a$ információellátottság javitása (és az ellátás technológiai fejlesztése), valamint a kommunikáció hatékonyságának növelése.

A dokumentumokhoz való hoz:áférés biztositása elósegiti az átláthatóság követelményének érvényre juttatását. A hozzáférésról több jogszabály született (pl. Regulation 1049/2001), de ehhez nélkülözhetetlen a megfelelő háttér, amit csak a többi, a konferencián is említett eszköz (pl. EUR-Lex) segítségével lehet elérni. Megfelelő hozzáférés nélkül a jogi szabályozást nem lehet érvényesíteni - ez az oka, hogy a konferencia a témájához látszólag nem illố transzparencia kérdéskörével is foglalkozott.

A transæparencia nélkülözhetetlen elemei az adatbázisok: az EUR-Lex, a Parlament és a Tanács nyilvános regisztere, továbbá a Bizottság által biztosított források (a dokumentumtár, a „komitológiai” regiszter, a PreLex adatbázis, valamint a foóigazgatóságok honlapjai).

Az információforrások javítása érdekében szükség van

- a Bizottság nyilvántartásainak bővítésére;

- felhasználóbarátabb honlapok kialakítására (idekapcsolódik az információs túlterhelés „information overflow" - jelensége);

- és még több dokumentum online publikálására (noha az interneten keresztül már most is elképesztố mennyiségú dokumentum érhetố el).

4. témakör: Az EU információs eszközei

A konferencián bemutatták az Unió jelenleg legjelentôsebb elektronikus és „hagyományos" publikációs médiumát, az EUR-Lex jogi adatbázist és az EU hivatalos $K i$ adóját.

A különféle információbázisokat a konvergencia miatt ma már a hordozók szerint egyre nehezebb szétválas:tani, mert például a Kiadó is növekvő számban jelentet meg elektronikus kiadványokat, és a dokumentumok egyre nagyobb része megjelenik mind nyomtatott, mind elektronikus formában.

Az EUR-Lex adatbázist két évvel ezelốtt újították meg, jelenleg 23 nyelven érhetô el, és munkanapokon kb. 200 ezer felhasználót szolgál ki.

2006-ban komoly programok indultak meg új kommunikációs módszerek kidolgozásá$r a$, valamint a rendszer felkészítésére a Bulgária és Románia csatlakozásával együtt járó új nyelvi tartalmak fogadására.

Az EUR-Lex szerkesztói az alábbi területeken tervezik a rendszer további fejlesztését:

- növelni kívánják az adatbázist, és az új - román, bolgár, ír - hivatalos nyelveken is meg fogják jeleníteni a tartalmakat;

- a teljes közösségi joganyagot fel kívánják tölteni a rendszerbe, amilyen hamar csak lehetséges - ez mintegy 10 ezer oldalnyi szöveget jelent nyelvenként - a feladat teljesítésének tervezett határideje 2006. december 15 ; 
- gazdagítani szeretnék a tartalmakat (idetartozik a jogi szövegek táblázatainak és mellékleteinek csatolása kereshető módon, képek beillesztése, a vonatkozó sajtóközlemények feltöltése és a szövegek HTML-formátumú konszolidációja).

Az anyagok feltöltése egyelóre 1998-ig visszamenóleg van folyamatban.

Az EU Official Publications, az Unió hivatalos kiadója szintén kiemelkedő szerepet játszik ezen a területen. A Kiadó meghatározott éves terv alapján múködik, felügyeli a szerzói jogokkal kapcsolatos ügyeket és katalógusokat készít. Az anyagok mennyiségét jelzi, hogy a Kiadóba mintegy 160 különbözó helyról érkeznek a publikációk.

Egyik fố tevékenységük az adatok strukturálása, és $a \approx$ új technológiák elterjedése köovetkeztében feladatukká vált az elektronikus archiválás is.

A Kiadó próbál megfelelni a változó igényeknek, ezért a kiadási és terjesztési tevékenységben üj irányelveket alkalmaznak.

Az új politika jellemzói a következók:

- kevesebbet eladni, de azt jobban;

- nörehni a nonprofit tevékenységet.

A kiadói tevékenység javításának szempontjai:

- az tekinthető ,jó" információnak, ami hasznos;

- fel kell használni a létező információs csatornákat;

- az ingyenes terjesztés a tapasztalatok szerint nem megfelelő forma még közcélú adatoknál sem, míg az eladás - akár jelképes áron is - biztosítja, hogy ahhoz jut el az információhordozó, akinek valóban szüksége van rá, és így elkerülhetố a „katalógusgyújtés" jelensége;

- a valós igényeket kell kielégíteni, ami azt jelenti, hogy csak azokon a nyelveken adják ki az anyagokat, amelyiken tartalmuk releváns lehet (pl. a mélyvízi halászattal kapcsolatos kiadványokat nem indokolt az összes uniós tagállam nyelvén kiadni).

A Kiadó az elmúlt időszakban - fóként az elektronizáció erősödésével - több gigantikus feladatot kapott. Teljessé kívánják tenni az „EU Könyvesboltot” (http://bookshop. europa.eu), ami azt jelenti, hogy távlati céljuk minden olyan anyag elérhetôségének a biztosítása, amit az EU és jogelődjei valaha is kiadtak. Egyelőre 2003-ig visszamenóleg digitalizálják és teszik elérhetoové az anyagokat, és az ő feladatuk kiépíteni az Unió virtuális könyvtárát.

Az Európai Unió Kiadója be kívánja vezetni az úgynevezett digitálisobjektumazonosító rendszer (Digital Object Identifier, DOI) használatát, ami tulajdonképpen digitális ISBN-nek tekinthetô, és elónye, hogy bármilyen adategységre alkalmazható (www.doi.org).

Meg kell említeni, hogy a Wikipedia szabad szerkesztési modelljét már használják professzionális célú adatbázisoknál is (például a European Sources Online esetében). A tartalom felügyelése érdekében ezt nem teljesen szabad, hanem „felülszerkesztett” formában oldják meg, ellenórizve a beírásokat.

A konferencia témáival kapcsolatban szabadon és teljes terjedelemben letölthetốk az alábbi anyagok: 
1. The European Ombudsman: The European Code of Good Administrative Behaviour. http://www.ombudsman.europa.eu/code/en/default.htm

2. The European Ombudsman: Could He help You? http://www.ombudsman.europa.eu/media/en/default.htm

3. European agencies working across Europe for you. http://osha.europa.eu/publications/other/20050719/index.htm?language=en

4. Commission of the European Communities: White paper on a European Communication Policy. http://ec.europa.eu/communication_white_paper/doc/white_paper_en.pdf

5. Information Note from Vice President Wallström to the Commission Plan D - Wider and deeper Debate on Europe. http://ec.europa.eu/commission_barroso/wallstrom/pdf/SEC2006_1553_en.pdf

Az alábbi két dokumentum - bár elektronikus formában jelenleg nem tölthető le - díjmentesen megrendelhetố az Európai Gazdasági és Szociális Bizottság honlapján (http://www.eesc.europa.eu), valamint másolatban kikérhetố a Tudásbankból (lásd alább):

1. European Economic and Social Committee

How to organise stakeholders' forums using 'Open Space Technology'

2. European Economic and Social Committee

Bridging the Gap - how to bring Europe and its citizens closer together

A konferenciáról részletes beszámoló olvasható az Infinit Intelligence Bt. Konferencia Tudásbankjában: http://www.konferencia-tudasbank.hu/ 